\title{
THE PREVALENCE OF CHIKUNGUNYA ARBOVIRAL INFECTION IN AND AROUND BELLARY DISTRICT, KARNATAKA.
}

\author{
Narayan Shrihari, Kumudini T. S, Mariraj. J, Krishna. S
}
1. Assistant Professor, MD. Department of Microbiology, Vijayanagar Institute of Medical Sciences (VIMS),Cantonment area, Bellary, Karnataka, India
2. Tutor D Bact, Department of Microbiology, Vijayanagar Institute of Medical Sciences (VIMS),Cantonment area, Bellary, Karnataka, India
3. Professor, MD. Department of Microbiology, Vijayanagar Institute of Medical Sciences (VIMS),Cantonment area, Bellary, Karnataka, India
4. Professor \& Head, MD. Department of Microbiology, Vijayanagar Institute of Medical Sciences (VIMS),Cantonment area, Bellary, Karnataka, India

\section{CORRESPONDING AUTHOR}

Dr. Narayan Shrihari, Assistant Professor, Department of Microbiology, Vijayanagar Institute of Medical Sciences (VIMS), Cantonment area, Bellary, Karnataka, India. E-mail: shriharimicro@gmail.com, Ph: 00919481710655.

ABSTRACT: BACKGROUND: An arbovirus is one that multiplies in a blood sucking arthropod and is transmitted by the bite to a vertebrate host. Chikungunya fever is a crippling disease caused by an arbovirus transmitted to human through mosquitoes. The sudden onset of very high fever along with rash and severe arthralgia are main symptoms. High morbidity with severe arthralgia persisted for several months made the people both physically and mentally weak. OBJECTIVES: To know the prevalence of chikungunya arboviral infection in and around Bellary district. MATERIAL AND METHODS: The laboratory records of clinically suspected chikungunya patients from January 2009 to December 2011 analyzed retrospectively and results of Ig $M$ anti chikungunya antibodies tested by Ig $M$ capture enzyme linked immunosorbant assay (Mac ELISA). RESULTS AND CONCLUSION: A total of 1386 chikungunya suspected serum samples were analyzed, out of which $343(24.75 \%)$ samples were fond positive for chikungunya virus infection. Maximum number of positive cases was seen in 2010 (28.40\%). The present study emphasizes the continuous sero- epidemiological surveillance for the effective chikungunya arboviral infection control programme.

KEY WORDS: Chikungunya and Ig M antibody capture ELISA

INTRODUCTION: The arboviruses are transmitted by blood sucking arthropods from one vertebrate host to another. The vector acquires a lifelong infection through the ingestion of blood from a viremic vertebrate host. The viruses multiply in the tissues of the arthropod without evidence of disease or damage. Some arboviruses are maintained in nature by transovarian transmission in arthropods [Figure No: 1]. The major arboviral diseases distributed worldwide are yellow fever, dengue, Japanese B encephalitis, chikungunya , St. Louis encephalitis, western equine encephalitis, eastern equine encephalitis, Russian spring summer encephalitis, westnile fever and sand fly fever [1]. Chikungunya virus (CHIK V) is a RNA virus belonging to family Togaviridae, genus Alphavirus. The disease caused by bite of Aedes aegypti mosquito (Man-Mosquito-Man). The incubation period one to seven days, characterized by abrupt onset of fever, severe arthralgia and disease is almost self limiting. The literal 
meaning of chikungunya is "that which bends up" that stooped posture developed due to arthritic symptoms of the disease [2]. The disease is generally non-fatal and the acute phase resolves within three to four days leaving the arthralgic syndrome persisting for some more time. The serological studies have repeatedly demonstrated the presence of antibodies in human [2,3]. Incubation period one to seven days, CHIK V produces disease about 48 hours after mosquito bite. Viraemia declines within three to four days [2,3]. Neutralizing antibodies can usually be detected after five days fading viraemia[2]. All age groups were affected including newborns. Recovery from the disease varies by age and longer for elders. Younger patients recover within 5-15days and middle agers recover in one to three months [2]. Chikungunya fever is an acute illness characterized by a sudden onset of high fever, rash and joint pain. The most significant symptom of CHIK V related disease consists of a painful arthralgia that occurs in almost $100 \%$ of patients. Most infections completely resolve within weeks but there are reported cases of CHIK V induced arthralgia lasting for months or even for years in the form of recurrent or persistent episodes [2,4].The clinically suspected cases screened using immunochromatography test kits (Rapid tests) and followed by ELISA detection of Ig M antibodies and confirmed by virus isolation and virus nucleic acid in sera by RT-PCR [5] The vector-borne disease and mosquitoes breeding sites are playing an important role in the transmission and propagation of chikungunya. The present study briefly describes the disease in general, laboratory diagnosis and the prevalence of chikungunya in and around Bellary.

MATERIAL AND METHODS: The study was conducted at a tertiary care Hospital from January 2009 to December 2011. A total of 1386 serum samples from suspected chikungunya cases included in our study. Aseptic precautions, two to five $\mathrm{ml}$ of blood samples were collected by venipuncture for chikungunya suspected cases. The samples transported to the Microbiology laboratory in vaccine carriers with duly filled requisition forms. The serum was separated by centrifugation of the whole blood sample and labeled with the particulars of the patient and stored in the refrigerator at $-20^{\circ} \mathrm{C}{ }^{[6]}$. The test kits used chikungunya Ig $\mathrm{M}$ antibody capture ELISA supplied by Group leader, Arbovirus Diagnostics, National Institute of Virology, Pune, India. The tests performed strictly as per the manufacturers' instructions.

RESULTS: During the three years of study period, 1386 Chikungunya suspected serum samples were analyzed, out of these $343(24.75 \%)$ samples were positive for Chikungunya virus infection [Table No: 1]. The prevalence of Chikungunya is high in 2010 (28.40\%) [Table No: 2]. Male to Female ratio of fever diagnosis in suspected cases is 0.98 [Table No: 3] and majority of cases belong to age group more than 15 years [Table No: 4].

DISCUSSION: The 2005-2006 epidemics in Indian Ocean island was the most devastating and had very complicated clinical manifestations associated with encephalopathy and hemorrhagic fever [7]. Arthralgia persisted for months and years with excruciating pain in joints and ankles [7,8]. The most affected were the aged adults and suffering from diabetes, alcoholic hepatopathy and impaired renal functions [7,9]. In India, Ahmedabad city, Gujarat and Kerala states experienced large scale out breaks with morbidity and extensive incapacitation [7]. The Kerala state had worst epidemic as the infection run through 2006 to 2008 affecting the whole state. Unique complications such as swollen limbs with painful arthralgia which persisted for long periods were witnessed among the patients [7]. Karnataka state also more affected during 2006 outbreak, 27 Districts of the state reported over (54.74\%) suspected cases. Several districts of 
the state such as Bellary, Gulbarga, Tumkur, Bidar, Raichur, Dharwad, Chitradurga, Davangere, Kolar and Bijapur have reported more number of chikungunya cases during epidemic outbreak [10]. More than $64 \%$ of the entire suspected cases in reported in India during 2008 [10]. We have noticed that chikungunya outbreak in and around Bellary. The number of confirmed cases are more in 2010 (28.40\%) than in 2009 (23.07\%) and subsequently decreased in 2011(19.05\%) [Table No: 2]. All three years statistics revealed that majority of the cases belong to age group of 15 years and above [Table No: 4]. The serological study indicated that arthropod-borne virus Chikungunya was prevalent in and around Bellary district, although the prevalence differed according to age, sex, geographic location and the individual virus. The geographical distribution had a significant influence on the prevalence of antibodies to the virus. This might be explained by the possible impact of ecological characteristics of the areas on the natural cycles of the arthropod-borne viruses under consideration [11]. Chikungunya disease recently emerged as an important public health problem in India. The epidemic occurs in the Indian Ocean islands during 2006[12]. More than 64\% of the entire suspected cases reported in India during 2008 [13]. We have noticed that Chikungunya outbreak in and around Bellary district. The number of confirmed cases were more in 2010 (28.40\%) than in 2009 (23.07\%) and subsequently decreased in 2011 (19.05\%).

CONCLUSION: The arboviral infections mainly dengue, chikungunya and Japanese B Encephalitis are most common in tropical and subtropical regions. Until the recent epidemic, CHIK V did not receive much attention due to low mortality, infrequent occurrence and absence in the developed countries. The serological results (Ig M antibody capture ELISA) clearly establish the etiology.

KEY MESSAGE: Prevention is better than cure.

\section{REFERENCES:}

1. Jawetz, Melnick, Adelberg, Arthropod borne and Rodent borne viral diseases In: Medical Microbiology, Chapter 38, 23 $3^{\text {rd }}$ edition, Singapore, The Mc Graw Hill Companies; 2004:514.

2. Chhabra M, Mittal V, Bhattacharya D, Rana UVS, Lal S, Chikungunya fever: A re-emerging viral infection, Indian Journal of Medical Microbiology, 2008; 26(1): 5-12.

3. Srikanth P, Sarangan G, Mallilankaraman, Nayar SA, Barani R, Mattew T, et al, Molecular Characterization of Chikungunya virus during an outbreak in South India, Indian Journal of Medical Microbiology, 2010; 28(4): 299-302.

4. Cavrini F, Gaibani P, Pierro AM, Rossini G, Landini MP, Sambri V, Chikungunya: an emerging and spreading arthropod-borne viral disease, Journal of Infection in Developing Countries, 2009;3(10): 744-752.

5. Alyson Kelvin A, Outbreak of Chikungunya in the Republic of Congo and the Global picture, Journal of Infection in Developing Countries, 2011; 5(6): 441-444.

6. Anuradha SK, SurekhaYA, Sathyanarayan MS, Suresh S, Krishna S, Satish SP, Mariraj J, Ravikumar R , Japanese Encephalitis virus; common cause of viral encephalitis in paediatric age group in Bellary, Karnataka, India, Journal of Clinical and Diagnostic Research, 2011; 5(3): 480-482.

7. Sudeep AB, Parashar D, Chikungunya: an overview, Journal of Bioscience, 2008; 33(4): 443-449. 
8. Pialoux G, Gauzere BA, Jaureguiberry S, Strobel M, Chikungunya : an epidemic arboviruses, Lancet Infectious Diseases, 2007; 7:319-327.

9. Couderc T, Chretien F, Schilte C, Disson O, Brigitte M, Guivel BF, Touret Y, Barau G, et al, A mouse model for Chikungunya: young age and inefficient type-I interferon signaling are risk factors for severe disease, PLoS Pathogens, 2008; 4:29.

10. Talawar AS, Pujar HS, An outbreak of Chikungunya epidemic in South India-Karnataka, International Journal of Research and Reviews in Applied Sciences, 2010; 5(3): 229-234.

11. Padbidri VS, Wairagkar NS, Joshi GD, Umarani UB, Risbud AR, Gaikwad DL, Bedekar SS, Divekar AD, Rodrigues FM, A serological survey of Arboviral diseases among the Human population of the Andaman and Nicobar islands, India, Southeast Asian Journal of Tropical Medicine and Public Health, 2002; 33 (4): 749-800.

12. Ukey PM, Bondade SA, Paunipagar PV, Powar RM, Akulwar SL, Study of seroprevalence of dengue fever in Central India, Indian Journal of Community Medicine, 2010; 35: 517519.

13. Kalantri SP, Joshi R, Riley LW, Chikungunya epidemic: An Indian Perspective, National Medical Journal of India, 2006; 19: 315-322.

Table No: 1 Distribution of suspected and confirmed Chikungunya cases

\begin{tabular}{|l|l|l|}
\hline Suspected Cases & Confirmed Cases & Percentage \\
\hline 1386 & 343 & 24.75 \\
\hline
\end{tabular}

Table No: 2 Distribution of Chikungunya suspected and confirmed cases according to year

\begin{tabular}{|l|l|l|l|}
\hline Year & Suspected Cases & Confirmed Cases & $\begin{array}{l}\text { Percentag } \\
\text { e }\end{array}$ \\
\hline 2009 & 802 & 185 & 23.07 \\
\hline 2010 & 500 & 142 & 28.40 \\
\hline 2011 & 84 & 16 & 19.05 \\
\hline Total & 1386 & 343 & 70.52 \\
\hline
\end{tabular}

Table No: 3 Distribution of clinically suspected cases according to gender

\begin{tabular}{|l|l|}
\hline Gender & Suspected Cases \\
\hline Male & 689 \\
\hline Female & 697 \\
\hline Total & 1386 \\
\hline
\end{tabular}

Table No: 4 Distribution of clinically suspected cases according to age

\begin{tabular}{|l|l|}
\hline Age in Years & Suspected Cases \\
\hline Less than 5 & 12 \\
\hline 5 to 10 & 38 \\
\hline 10 to 15 & 261 \\
\hline More than 15 & 1075 \\
\hline Total & 1386 \\
\hline
\end{tabular}

Journal of Evolution of Medical and Dental Sciences/Volume1/Issue5/November-2012Page-680 
Figure No: 1

Arbovirus life cycle

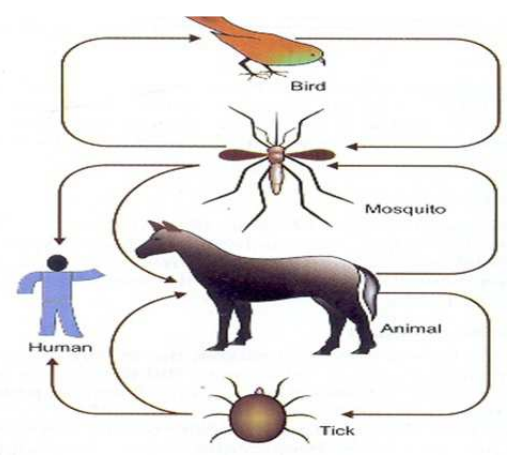

